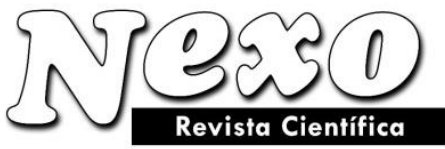

ISSN-E 1995-9516

Universidad Nacional de Ingeniería COPYRIGHT (C) (UNI). TODOS LOS DERECHOS RESERVADOS http://revistas.uni.edu.ni/index.php/Nexo https://doi.org/10.5377/nexo.v34i06.13140

\title{
Choosing a methodological base for forming and accounting for the construction costs of a gas well at the final stage of field development
}

\section{Eligiendo una base metodológica para la formación y la contabilidad de los costos de construcción de un pozo de gas en la etapa final de desarrollo de campo}

\author{
Valery A. Chejmatova*, Yuriy V. Vaganov \\ Tyumen Industrial University, Tyumen, Russia. \\ "email: chejmetovava@tyuiu.ru
}

(recibido/received: 22-septiembre-2021; aceptado/accepted: 02-diciembre-2021)

\begin{abstract}
The article introduces the problems of choosing a methodological base for forming and accounting costs during well construction, taking into account the intensification of gas inflow at the final stage of field development. The main methods that allow taking into account the costs of drilling operations are outlined. The main costs that need to be taken into account when designing fields with hard-to-recover gas reserves are identified and characterized. The main stages of cost formation by construction phases of a gas-producing well are shown, as well as the factors influencing the level and structure of the cost price during the construction of a well are highlighted. The authors consider the classification of cost accounting methods in the context of the comparison criterion and present the possible results of the correct choice of the cost formation method during the construction of a gas well at the final stage of its development.
\end{abstract}

Keywords: hard-to-recover reserves; gas production; tectonic elements; Arctic regions.

\section{RESUMEN}

El artículo presenta los problemas de elegir una base metodológica para la formación y contabilizar los costos durante la construcción del pozo, teniendo en cuenta la intensificación del flujo de entrada de gas en la etapa final del desarrollo del campo. Se describen los principales métodos que permiten tener en cuenta los costos de las operaciones de perforación. Se identifican y caracterizan los principales costos que deben tenerse en cuenta al diseñar campos con reservas de gas difíciles de recuperar. Se muestran las principales etapas de formación de costos por fases de construcción de un pozo productor de gas, así como los factores que influyen en el nivel y estructura del precio de costo durante la construcción de un pozo. Los autores consideran la clasificación de los métodos de contabilidad de costos en el contexto del criterio de comparación y presentan los posibles resultados de la elección correcta del método de formación de costos durante la construcción de un pozo de gas en la etapa final de su desarrollo.

Palabras claves: reservas difíciles de recuperar; producción de gas; elementos tectónicos; Regiones árticas 


\section{INTRODUCCIÓN}

Raw hydrocarbons are currently one of the main sources of increasing the welfare of Russia. Therefore, the search, exploration, and development of existing and promising fields, both in traditional gas production areas and new gas provinces, is one of the most important challenges for both the economy of the state, the region, as well as the company. Nevertheless, the reserves of high-quality hard-to-recover raw hydrocarbons within the known and exploited areas are especially valuable. Their development and operation require attracting additional costs for the development of social, industrial, and transport infrastructure, which is the main factor affecting the cost of drilling operations during well construction.

In the context of insufficiency of various types of resources, such as financial, economic, investment, etc., due to the unstable macroeconomic situation and changes in the development trends of the world energy market, the problem of reducing the level of costs is becoming very urgent. First of all, this concerns the work on intensifying the inflow of hard-to-recover hydrocarbon reserves, in terms of drilling operations. This problem is relevant not only for the customer of various types of drilling operations but also directly for the organization, contracting drilling services. Accordingly, the ways and methods of reducing costs during the intensification of the inflow of hard-to-recover hydrocarbon reserves, and in particular the cost of well construction, are specific and thus of interest in terms of the interaction between the customer and the contractor (Pravosudov, 2014).

The development and construction of wells with hard-to-recover gas reserves are considered to be successfully implemented when setting and implementing a goal, such as achieving the estimated minimum increment in gas production while reducing the extraction of associated water in the conditions of the stable near the well-bore area to improve the economic efficiency of the work performed in general (Vaganov y Kustyshev, 2016; Vaganov y Cheymetova, 2020).

The contemporary development of the gas industry on a global scale leads to the employment of new, more expensive technologies and the conduction of scientific and innovative research in the field of subsurface use, which also leads to an increase in the costs of prospecting, exploration, and extraction of raw hydrocarbon.

However, there are also significant reserves for identifying and using them, which helps to reduce the period of field exploration and improve the efficiency and intensification of gas inflow at the final stage of field development, which will lead to cheaper production of raw hydrocarbons in the future (Vaganov, et al. 2017; Vaganov y Katanov y Listak, 2020).

Considerable reserves are hidden in improving the quality of completion of gas formations during drilling, improving the well design, and reducing the metal consumption of structures, increasing the durability of fastening, and separating gas-bearing horizons. The cost of well construction is one of the most important generalizing indicators of production efficiency since a change in its value directly affects the amount of profit, and the lower the prime cost, the more profit can be obtained (Vaganov y Cheymetova, 2020).

The analysis of previously developed methods for forming costs for the construction of wells has shown that to date no fully developed and tested methodological approaches are available, which confirms the relevance of the research in this area.

\section{METHODS}

Forming the prime cost during the construction of a gas-producing well should reflect the entire complex of drilling operations. This is a series of successive stages that leads to a gradual increase in costs that corresponds to the next construction stage of a gas-producing well (Figure 1). 
The prime cost of well construction consists of the features of drilling wells, the technologies used, the category of reserves for further extraction, as well as the selected type of gas well, taking into account the intensification of the gas inflow. The work composition should account for costs at different stages of well construction, as well as the existing drilling conditions in the course of deepening the well, and the fact that the reserves are difficult to recover (Dunaev y Shpakov y Epifanova, 2010).

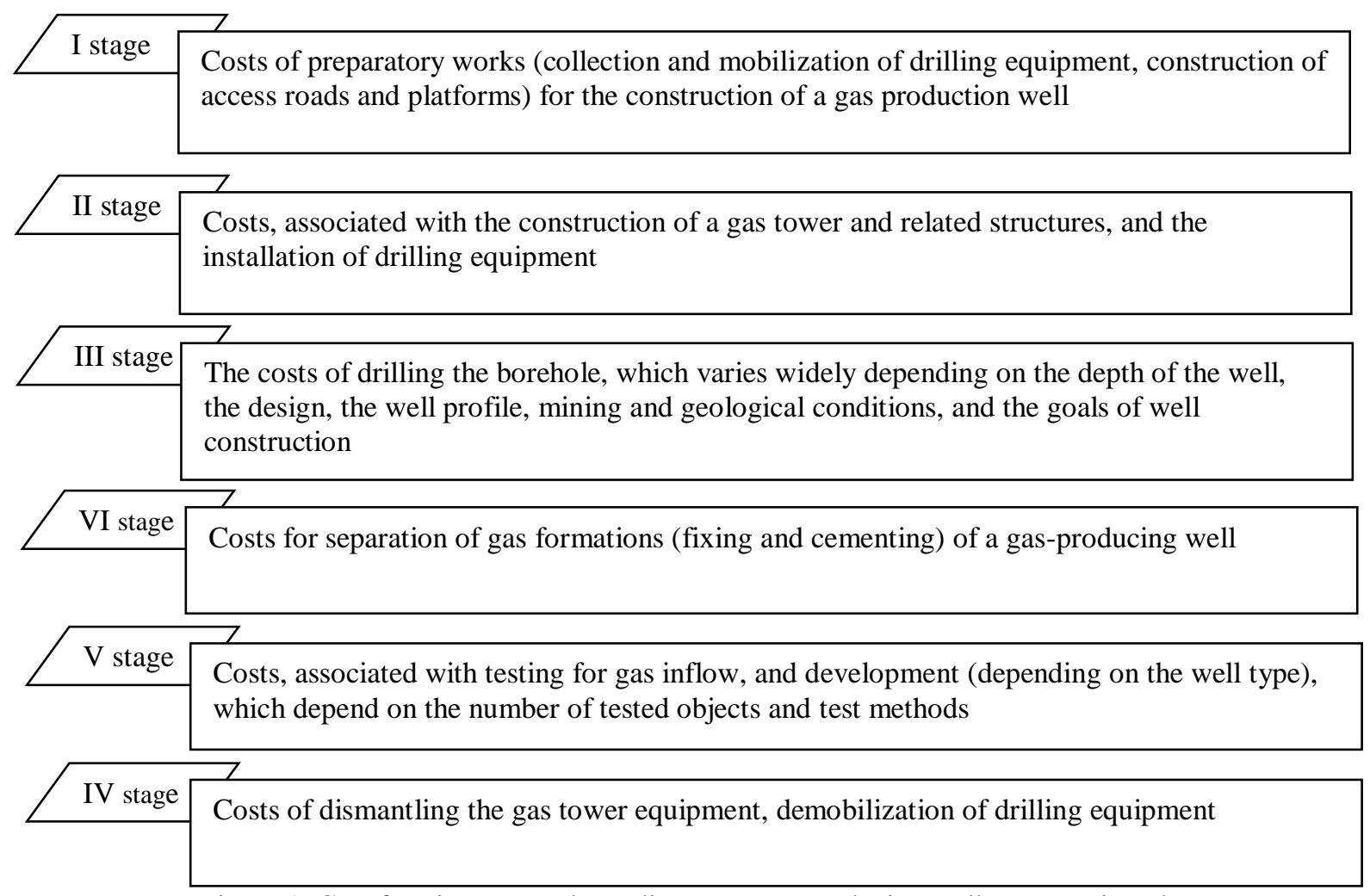

Figure 1. Cost forming stages depending on a gas-producing well construction phases

When drilling gas wells, it is necessary to identify its construction stages, which form the basis for making estimates for the construction period, taking into account and scheduling production throughout the cycle, as well as forming a cost budget promptly according to a specific stage.

The cost level and structure of the gas well construction are simultaneously influenced by a complex set of factors (Mitskevich, 2009).

1. Factors that determine the technical and organizational level of work performed at a drilling enterprise, and, in particular, during well construction.

2. Geological factors, such as:

- the size of the developed field, determined by the raw $\mathrm{h}$

ydrocarbon reserves;

- the degree and nature of the concentration of hydrocarbon reserves, in our case it is necessary to consider that the gas is low-pressure; 
- the shape of individual deposits, their number, spatial and mutual position, size, capacity, structure, and mode of occurrence, in our case, deposits of irrational development of gas fields;

- the quality of raw hydrocarbons, their material composition, and technological properties;

- mining and technical conditions for the formation opening up and a field operation with difficult-torecover reserves of raw hydrocarbons.

3. Economic and geographical factors, determined by the location of the gas deposit in the region, the presence of developed transport, and social infrastructure (Shapovalov, 1984; 1991).

When drawing up a plan for the construction cost of a specific well, the sum of all costs for the drilling company is set in general, which must be carried out in the planned year for the established amount of work on the construction of all wells of a concerned enterprise which performs drilling, as well as the costs for each subdivision that is part of the drilling enterprise (Kovalev, 2009).

The estimate for the construction of any type of well determines the amount of all costs required to perform drilling operations. It is made based on the technical design of the well, which should reflect the following elements:

- the volume of individual works on drilling a specific well;

- features of the well design;

- drilling technology that will be used;

- organization of the well drilling process;

- the planned drilling rate of the well.

When developing an estimate, it is also necessary to use a directory of unified estimated costs, which include elemental estimate standards, unified regional prices for the construction of wells, unified regional prices for material resources and the required equipment, regional transport tariffs, regional overhead costs, and planned accumulation rate (Repin, 2015).

The construction costs of any type of well are determined by performing a series of estimated financial calculations. The first calculation includes the calculation of the costs that are necessary to perform preparatory work on well construction. The second one is made according to the costs of construction and disassembly of the gas tower and associated structures. The third calculation is based on the costs of installation and dismantling of entire drilling equipment necessary for well construction (Vasiliev y Dubina, 2011).

All three types of the above calculations are made according to a single formula:

$$
\mathrm{Z}_{\mathrm{i}}=\mathrm{O}_{\mathrm{i}} *\left(\mathrm{~g}_{\mathrm{i}}+\mathrm{M} * \mathrm{~S}_{\mathrm{r}}\right)+\mathrm{O}_{\mathrm{i}}^{*} \mathrm{~g}_{\mathrm{p}}-\mathrm{O}_{\mathrm{i}} * \mathrm{~g}_{\mathrm{B}}
$$

$\mathrm{Z}_{\mathrm{i}}-$ costs for well construction according to the $\mathrm{i}$-th article, ruble;

$\mathrm{O}_{\mathrm{i}}$ - the physical volume of drilling operations according to the $\mathrm{i}$-th article;

$\mathrm{g}_{\mathrm{i}}$ - the price per unit of drilling operations according to the $\mathrm{i}$-th article, ruble; 
$\mathrm{M}$ - the number of required loads per unit of drilling operations, ton;

$\mathrm{S}_{\mathrm{r}}-$ the cost of transporting 1 ton of cargo to the distance provided for by the technical project, ruble;

$\mathrm{g}_{\mathrm{p}}$ - the price for disassembly per unit of drilling operations taking into account the unified regional unit rates (URUR), ruble;

$\mathrm{g}_{\mathrm{B}}-$ the cost to return materials per unit of drilling operations, ruble.

The fourth calculation includes all the costs that relate directly to the production of drilling. The fifth calculation is made directly for well cementing, which is divided into two types.

The first type is the costs that depend directly on the time $\mathrm{Z}_{\mathrm{v}}$. They are proportional to the days of drilling and cementing. This type of cost includes:

- labor costs for all members of the drilling crew;

- the cost of maintaining drilling equipment and all drilling tools;

- depreciation of drilling equipment;

- the costs of spare parts and material resources that are spent in the course of operation of drilling equipment;

- the cost of maintaining bottom-hole engines;

- the cost of energy, water, and chemical reagents required for well construction;

- the cost of transport, which is used for the transportation of materials.

The second type is the costs that depend on the volume of sinking by boring $\mathrm{Z}_{\mathrm{p}}$ (its depth and diameter), which depend on the drilling volume (one $\mathrm{m}$ of sinking), the consumption of used bits, wear of drill pipes, etc.

The costs for each item (dependent on time and volume) are summed up by columns. The amount of consumable materials is defined in the requirement description for well construction.

The sixth type of the estimated financial calculations should include cost for testing the well which is formed from the following expenses:

- payment of the labor of the testing team;

- maintenance and depreciation of drilling equipment;

- wear of the entire drilling tool;

- energy, industrial water;

- transport, for the transportation of the testing team and material resources. 
Besides the six financial estimations, it is necessary to determine the following daily depreciation charges for all drilling equipment and wear of the drilling tool.

The total estimated cost of well construction will be determined by the formula:

$$
\mathrm{S}=\mathrm{Z} 1+\mathrm{Z} 2+\mathrm{Z} 3+\mathrm{Z} 4+\mathrm{P}
$$

where

$\mathrm{Z} 1$ - the direct cost of well drilling;

Z2 - overhead costs for well drilling;

Z3 - additional costs, which include remuneration for the employees' service record, field allowances for employees working at the field, and allowances for work in the Far North;

Z4 - other costs, which include topographic and geophysical costs (determined by the URUR), the costs of carrying out all laboratory work necessary for well construction;

$\mathrm{P}$ - planned savings of the drilling enterprise.

The estimated cost of penetration per one meter is determined by the following formula:

$$
\mathrm{CC} \mathrm{MP}=\left[\sum \mathrm{Ci} * \mathrm{Si}\right] /\left[\sum \mathrm{Si} * \mathrm{hi}\right]
$$

where

$\mathrm{Ci}$ - the estimated cost of the well;

$\mathrm{Si}$ - the number of wells of the i-th group, provided for by the drilling process;

hi - depth of the i-th well.

The planned estimated cost of well construction is determined in two ways:

1) according to the estimates for technical projects, drawn up and approved in the planned year;

2) based on the level of costs in the first year, but adjusted for possible changes in comparison with the technical project of commercial drilling rate, well depths, and taking into account factors of a geological, technical, and organizational nature.

The estimated cost of the planned volume of drilling operations is determined by the drilling methods by multiplying the weighted average values of the estimated cost of a meter of operational and exploration drilling by the planned volume of penetration in production and exploration wells.

The planned cost of well construction is often less than its estimated cost by the amount of planned savings and planned prime cost reduction due to internal factors. This results mainly from an increase in the drilling rate which respectively leads to the reduction of two following costs:

- time-dependent costs due to the acceleration of well drilling; 
- costs due to the planned and rational change in the consumption rates of material resources necessary for drilling a well (savings from drilling rate) and their prices.

\section{RESULTS}

Getting a positive result from the choice and application of a particular calculation method, namely, reducing the cost of well construction at the budget formation stage is quite possible but at that, it is necessary to consider several points.

Firstly, it is the implementation of innovative developments of equipment and technology in the industry, as well as well construction process automation. It should also be remembered that it is advisable to improve the technologies already available at the enterprise, implement advanced construction materials and consumables that will help to intensify the inflow from the wellhead more effectively and efficiently.

Secondly, it is necessary to consider the implementation of organizational and technical measures to increase the productivity of workers at all stages of the gas well construction, which will lead to a decrease in the share of wages in the cost structure.

Thirdly, one of the conditions for reducing the gas production cost is the implementation of a consistent saving mode at all stages of well construction, primarily this is aimed at reducing the cost of material resources cost of servicing the production process of well construction and management, as well as eliminating losses from defects, and other unproductive expenses.

Thus, the analysis of break-even (direct-costing system) activities is the main tool for current cost management. The value of this analysis lies in linking the decision-making on cost management with the dynamics of production volume, prices, and revenue. Therefore, we believe that the application of the above-mentioned cost management methodology will allow the enterprise to reduce the gas production cost and keep reliable cost accounting.

\section{DISCUISSION}

In the current context, drilling enterprises in the Russian Federation most often employ an integrated approach to control costs, which includes the following points:

- optimizing expenses at the stage of forming well construction budget, taking into account the intensification of inflow at the final stage of field development;

- developing and implementing a cost reduction program, which includes achieving the efficiency of procurement of goods, works, and services, necessary for well construction;

- implementing plans to optimize the costs of other types of activities at the enterprise.

There are various ways of accounting for production costs and calculating the cost of products used in well construction (Figure 2). Their choice is determined by the features of the production process, i.e. taking into account the intensification of the inflow of raw hydrocarbons at the final stage of field development (Shkarin y Khalitova, 2013). 


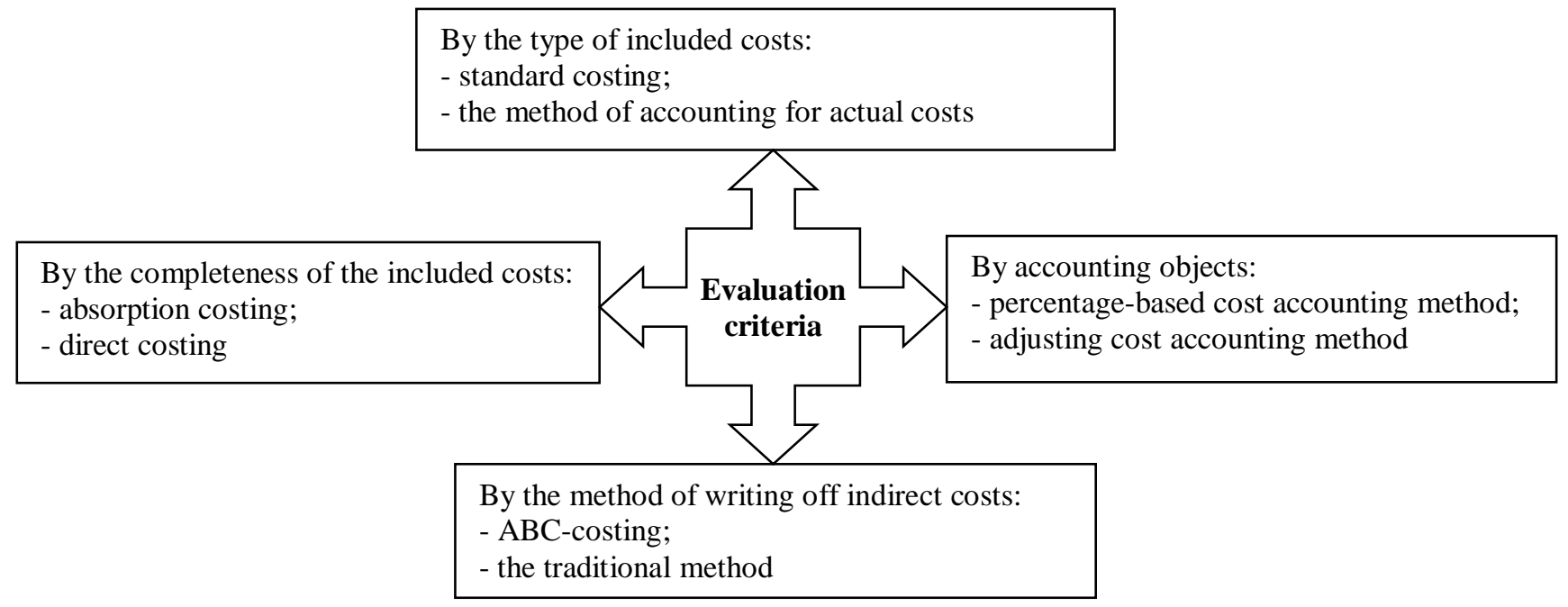

Fig. 2. Classification of cost accounting methods in the context of comparison criteria

One of the accounting methods of the total costs, called absorption costing is to account for the cost of well construction by dividing all costs into direct and indirect. This approach to calculation, which is also used in accounting, is very often used in drilling organizations.

The main advantage of this method is that it allows the executive of a drilling company to adjust the amount of reported profit based on changes in well construction schedule, while it is possible to consider the use of various methods and technologies for intensifying gas inflow at the final stage of field development.

When using the absorption costing method at a drilling company, several errors may occur:

1) the regulatory accounting error, which consists in the use of indirect cost rates calculated for a certain method of well construction, in situations related to another method;

2) error related to variability by period: all indirect costs for the month are summed up, and the amount is divided proportionally to the base, "dominating in the production process of well construction";

3) standard error: overestimation of well construction cost at the final stage of field development and underestimation of the cost of standard construction; a significant part of the pan costs is associated with the implementation of new projects;

4) imputing uncontrolled costs to the drilling company's divisions and business processes, which does not allow determining with acceptable accuracy how much the business process and technology cost, as well as to see the total amount of the division's costs;

5) unreliability of profit calculations.

Therefore, quite often the absorption costing method is replaced with another one, such as direct costing. 
Using this method allows getting rid of the variability error over periods, which shows that there is stability and accuracy of the incomplete cost price compared to the full cost price under unchanged conditions of well construction. The use of the direct costing method always allows showing the amount of operating profit fairly accurately. The amount of profit in these two methods will coincide, provided that the stocks at the enterprise were unchanged for a certain period.

The direct costing method is a technique of calculating the cost of well construction, in which all costs are divided into fixed and variable, but only the variable costs are attributed to the cost of the gas produced later on. The constant part of general production costs refers to the costs related to the period together with the marketing costs and administration.

When calculating the prime cost using the direct costing method, fixed costs, such as costs for fuels and lubricants for boiler and diesel power plants, communication services, labor protection services, and fire safety at the enterprise are excluded from the expenses for the main production (Dunaev, 2014).

Overhead costs at the drilling enterprise, in terms of accounting for fixed costs, are not included in the products (hydrocarbons) marketing costs and are repaid from the total marginal income of the enterprise, which is calculated as the difference between the revenue from the sale of gas and direct costs. It should be noted that with this method of cost accounting, the total cost does not include general economic costs.

In auxiliary production during well construction, such costs include personnel costs, communication services, security services, fire safety services, depreciation, rent, and insurance costs.

In general production costs, constant costs include energy and fuel costs, depreciation, and insurance costs at the drilling enterprise.

The need to use the direct costing method in management accounting at a drilling enterprise is because its application will allow quickly studying and identifying the relationships between the scope of work performed on well construction, as well as costs and the profit received. As a result, all this will allow estimating the prediction of the behavior and changes in the prime cost or certain types of costs when changing the methods and technologies used for well construction.

Consideration of other accounting methods is not rational, since they are not used at contemporary drilling enterprises. It is worth noting that the cost of well construction determines the sum of all costs of the drilling enterprise that must be incurred to perform the specified amount of work, as well as the costs for each workshop and department that are part of the drilling enterprise (Dunaev y Shpakov y Epifanova, 2010, p. 147).

\section{CONCLUSIONS}

The choice of a methodological basis for forming and accounting costs during well construction must consider that gas inflow intensification is reached at the final stage of field development. In this context, it becomes important to conduct a detailed analysis of how the costs are taken into account at the drilling enterprise. To do this it is necessary:

1) to provide correct data on forming and accounting costs at the enterprise;

2) to process the submitted data to make it possible to manage the costs of all production process stages of well construction. 
When determining the method of forming the cost of drilling operations, it is also necessary to consider that at the moment there are no universal options either in scientific research or in practice.

When choosing a method for forming well construction costs, taking into account that the gas inflow intensification will be reached at the final stage of field development, it is necessary to consider the specifics of drilling operations in this context.

An important feature of drilling operations is the impossibility of direct observation of the drilling process since the equipment is located underground, rather than on the ground surface. This fact determines the uniqueness of using various technologies of the drilling process, as well as affects the formation of production costs at gas wells. It is also necessary to consider that there is currently no well-developed methodology for constructing a well in the conditions of implementing the procedure for intensifying gas inflow at the final stage of field development.

When forming costs for well construction, it is necessary to consider several features due to the production process of drilling operations, which includes the construction and subsequent transfer of the well to the direct customer, and therefore, there are no costs for raw hydrocarbon production in the prime cost (Shkarin y Khalitova, 2013). Implementing drilling operations during well construction requires large energy resources. Therefore their costs in the production process are attributed to an independent cost calculation item. In drilling lacks cost items such as semi-finished products and work-in-progress, which allows all production costs for a month to be written off in full to the cost of finished products. Besides, when conducting drilling operations, it is customary to divide the costs into those that depend on the drilling time, and those depending on drilling volume. The time-dependent costs are changed in proportion to the well drilling duration.

The seasonality of work affects the formation of working capital, and this typically concerns the Western Siberian territories. Almost all gas fields are located in autonomous isolation far from the developed transport and social infrastructure. Therefore, it is always necessary to create an annual supply of material resources and equipment at a time that diverts significant funds from the turnover of the drilling enterprise (Sorokin, 2003).

Lack of transport infrastructure development, due to the lack of roads in the summer period, forces to carry out all transportations in winter. In certain situations, when there are no roads even in winter, material resources and equipment can be transported only using air transport, which entails a significant increase in the cost of well construction.

It is important that when constructing a well, various types of contractual conditions for providing services to the customer can be used, namely,

- turnkey drilling, when the contractor performs all stages of well construction and development, as well as independently acquires all material resources at its expense;

- separated service, when the contractor provides only labor and drilling equipment for drilling operations;

- work, based on a give-and-take basis, when all material resources are provided by the customer himself, while the contractor provides a full range of services.

The choice of the type of services to be provided directly affects the cost of well construction.

The technical complexity of well construction process as well as implementing conditions at which the gas inflow intensification is reached at the final stage of site development are associated with increased risks 
that are difficult to determine at the stage of technical project development. The risks will have a significant impact on the final result of drilling operations, and, as a result, on construction costs.

\section{REFERENCES}

Dunaev, V.F. (Ed). (2014). Economics of oil and gas industry enterprises. Moscow: LLC Tsentralitneftegaz.

Dunaev, V.F., Shpakov, V.A., Epifanova, N.P. (2010). Economics of the oil and gas industry enterprises. Moscow: Centrotavola.

Kovalev, V.V. (2009). Analysis of the economic activity of the enterprise. Moscow: Prospect.

Mitskevich, A.A. (2009). Fundamentals of management accounting. Moscow: Higher School of Financial Management of the Academy of National Economy under the Government of the Russian Federation.

Pravosudov, S. (2014). Sustainable corporation. Gazprom Corporate Journal 12, 12-16.

Repin, A.G. (2015). Gas, and oil: a short glossary. Moscow: Scientific World.

Shapovalov, A.G. (1984). Analysis of the production and economic activity of a drilling enterprise. Moscow: Nedra.

Shapovalov, A.G. (1991). Design and financing of the oil and gas well construction. Moscow: Nedra.

Shkarin, D.V., Khalitova, E.G. (2013). Prospects for the development of a drilling enterprise from the standpoint of improving the budgeting and management accounting system. Bulletin of the Association of Drilling Contractors, 4, 13-19.

Sorokin, L.R. (2003). Contemporary management technologies in the oil and gas complex. Moscow: Moscow Institute of Physics and Technology.

Vaganov, Y., Cheymetova, V. (2020). Risk management at the final stage of gas field development. IIOABJ, 11(3), 31-35.

Vaganov, Y.V., Katanov, E.Y., Listak, M.V. (2020). Geological and mathematical description of the rocks strain during the behavior of the producing solid mass in compression (tension). Journal of Mines, Metals \& Fuels, 68(9), special issue.

Vaganov, Yu.V., Kustyshev, A.V. (2016). Assessment of the economic efficiency of complex well repairs in the changed operating conditions of gas wells. Problems of the Oil and Gas Complex Economics and Management, 1, 13-16

Vaganov, Yu.V., Yagafarov, A.K., Kleshchenko, I.I., Parfiriev, V.A. Popova, Zh.S. (2017). Geological aspects of producing reserves from complex gas deposits. International Journal of Applied Engineering Research 12(24), 16077-16082.

Vasiliev, Yu.N., Dubina, N.I. (2011). A systematic approach and methods of system analysis in the gas fields design and development. Moscow: Nedra Publ. 